\title{
Wildlife of the Otosquen Area
}

FRED G. BARD

Director of Provincial Natural History Museum.

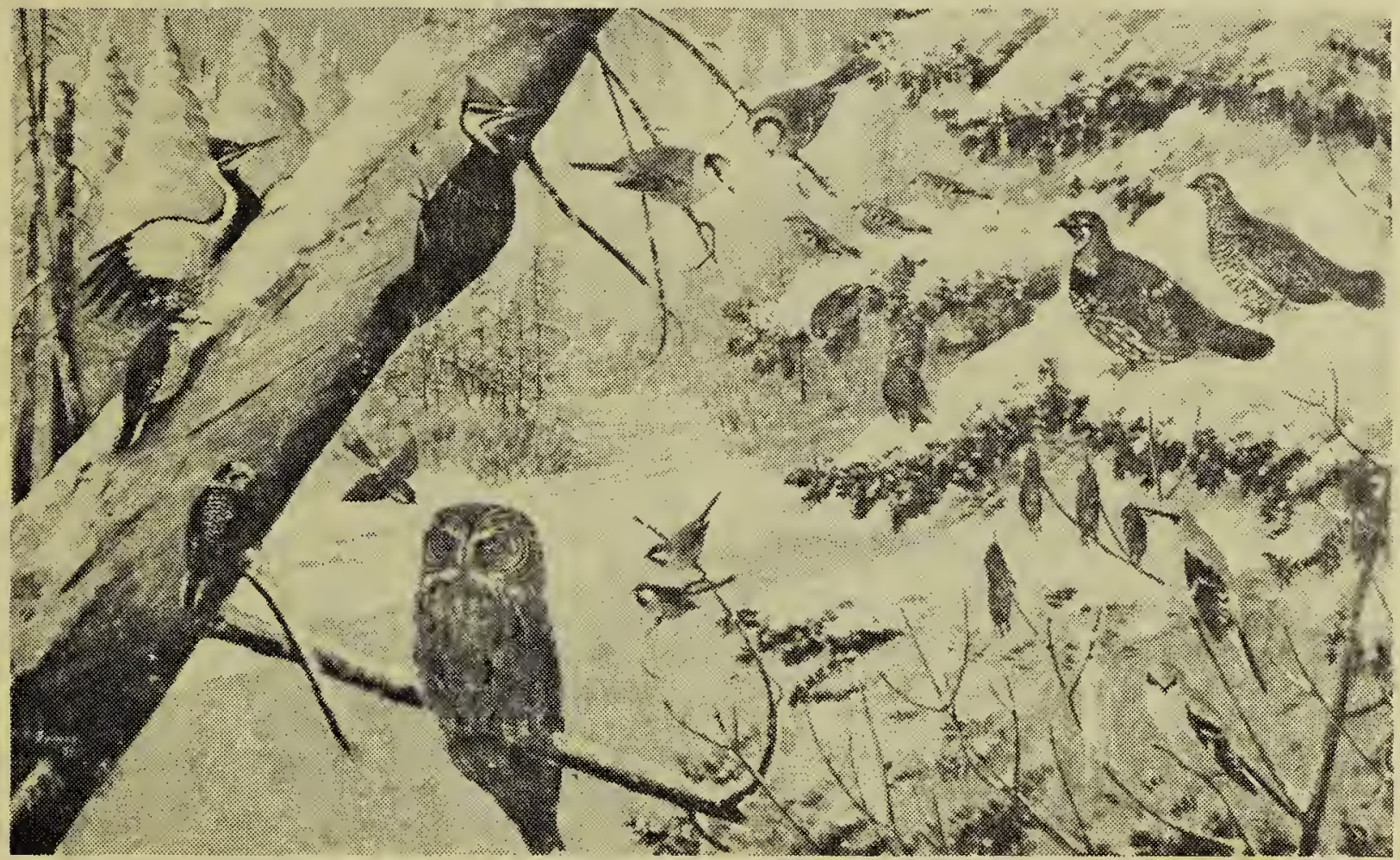

Pileated Woodpecker

Canada Jay

White-winged Crossbill

Arctic-three-toed Woodpecker

American Crossbill Spruce Grouse

American Three-toed Woodpecker Great Gray Owl

Hudsonian Chickadee

Meadow Mice

Northern Shrike

Bonapart's Weasel

On the railroad between Hudson Bay Junction, Saskatchewan and the $\mathrm{Pas}, \mathrm{Manitoba}$, is a siding at mile 31 , called Otosquen, meaning " the meeting place ", in Cree. The travelling Indians here crossed the steel; here the wilderness life was illustrated in contrast with modern day travel. Mr. Swanston, Museum Assistant, and I travelled to this region in search for specimens of Moose, following a discussion with Mr. Fred Warburton district Superintendent. We were escorted to the lease of Mr. Lyman Morrison by Sid Read, Game Guardian In driving to the camp site, birds were observed feeding along the road or flying over open cultivated fields. Among them were Snow Buntings, Bohemian Waxwings, one Goshawk, one Snowy Owl, and one, thought to be the Grey Cyrfalcon.

We occupied a cabin well constructed of logs, chinked with clay mortar and lined with building paper to make a very comfortable camp. With the assembling of the space heater, the smoke was soon curling its way to the tops of the spruce 80 to 100 feet high. By the time darkness had set in the camp was well in order. Our water supply was north about 300 yards, where a hole was cut in the ice of one of the tributaries of the Pasquia river. For washwater, we melted some of the snow which was piled deep and clean all through the woods.

The days were very short now, for we were in the darkest month of the year, and our first of ten days spent in the field was December 8 th. In company with Mr. Oscar stromberg, we Covered some of his trapping trails, working east through the burns and out to the creek again. Noon lunch was then pre pared around a warm fire in the field. By evening we were back in the camp Deer tracks were numerous and on a few occasions the White-tailed Deer were seen. A few Moose tracks were seen, but none seemed recent. As during our stay no Moose were sighted, we concluded they were just traveling through this particular area when reported to us. About dark, after returning to camp on the first day, from the Pasquia Hills to the north and west came 
a tremendous roar, answered by more deep coarse roars. This was our first s erenade by Timber Wolves. I now can easily understand the feelings of newcomers to the woods.

The great roar and the mental pictures of the wild stories telling of their ferocity is enough to hurry a nyone along. While the wolves, no doubt on occasion were close to us, we were never for tunate enough to havea glimpse of them. We searched every direction for Moose several days withoutsuccess. The great variety of winter birds in this area of the Canadian Zone, turned our efforts to gathering material required in our various family displays. Collecting in this region was very desirable and here was an opportunity to gather winter material. Besides the Arctic and American Three-toed Woodpeckers, the Downy and Hairy were collected. In addition a Black Poplar feeding stump and a pair of Pileated Woodpeckers were also collected. Travelling bands of Hudsonian Chickadees with their soft coarse " dee dee ', now changed into a musical song quite different from anything else we had heard. These chicadees were often met in the woods, travelling in bands with Longtailed Chicadees and Ped-breasted Nuthatches. These tiny creatures would flake chips from the spruce in their effort to feed. This work in the stillness of the woods sounded like that of birds twenty times their size. They were always in a hurry and would stay only a short time and then move on. Blue Jays were uncommon, in fact only two were seen. The Canada Jay, however was very plentiful. While their normal food appeared to be around, many of them readily accepted tidbits from the kitchen refuse heap. Canada Jays, Woodpeckers and Chickadees were always present at the se feeding stations. In fact one Canada Jay was flying around with all its tail feathers gone. The camp cat looked.longingly from the kitchen doorway, no doubt planning newerand better tactics. Other cheery winter whistlers, the Pine Gros beaks, refererd to in this area as Hudson Bay Robins, were noted in small bands. Usually each band was accompanied by one or two brilliant males: They usually fed at the cones on the tip of the Spruce. Red Squirrels were fairly numerous, and in one of our sets, a single flying squirrel was taken. The Squirrel cache is at the base of a Spruce, where great piles of cones are stored, blanketed down with the protecting s now. Squirrel trails in the loose snow lead to a little burrow, where the cones are withdrawn, the seeds eaten, leaving the husks gathered together in a little pile. When disturbed, they scurry well out of reach and scold loudly; sometimes they become rather curious and move in closer, then if frightened they scurry well in to the protecting branches of the trees with a burst of squirrel like remarks. Ruffed Grouse were seen usually at sundown as well as bands of Sharp-tailed Grous ef eeding on poplar buds: Spruce Grouse were seen as well. Varying Hares or Bush Rabbits, were common in the area, and two weasel, Bonapartes, were given to us by the trapper, Mr. Stromberg. White-winged Crossbills, Three Evening Grosbeaks, three Golden-crowned Kinglets, and one Brown Creeper were seen in one afternoon. No others were seen during our stay. Great Homed Owls were heard in the evenings and an occasional Paven croaking as it flew across the treetops; Magpies too were uncommon. Redpolls appeared twice in our daily treks. Fox and coyote tracks were seen every where. No signs of Caribou were found. Mr. Morrison said the Woodland Caribou had disappeared only a few years before. The Black Bears of the area were denned up for the winter. Beaver and Muskrats were in the district as indicated by the houses seen. Most animal tracks were scarce. One reason appeared to be that at about freeze up time a four inch rain had swollen the creeks and the water had froze $n$ at its new high. By the time the run off had gone there was a layer of ice roughly eight inches above the now open water and beneath this, mink and otter could move without being seen. This unusual ice condition had affected logging and fishing operations. Further north the crossing of these small creeks was hazardous for the ice was not thick enough to bear ones weight.

In the beginning we followed the trappers' trails; as we became more familiar with the area we often cut across from one to the other or struck out with the aid of our compass, circle and come back. I did not appreciate the significance of our operations until one day Mr. Stromberg qui etly remarked, 'My goodness but you fellows make' a lot of trails !" We then fully realized it would be a considerable relief to Mr. Stromberg when we had left the area and a newfall of snow had covered our maze of tracks so that he might carry on normally. We found these people co-operative and interested in our work, and they had a sincere desire to learn what we knew of Natural History. It is our hope to continue to visit new places and meet more people, that we also, may learn more of Natural History. Such experiences are essential in this job of building up our Natural History Museum. 